\title{
DRAG PERFORMANCE OLEH JAVANESE CROSS GENDER DALAM CABARET SHOW DI YOGYAKARTA
}

\author{
Langen Bronto Sutrisno, Sahid Teguh Widodo, Bani Sudardi, Warto \\ Universitas Sebelas Maret, Indonesia \\ langenbronto@yahoo.com
}

\begin{abstract}
Abstrak: Penelitian ini merupakan studi tentang drag performance yang meliputi drag queen, drag transgender, dan drag pria kemayu (feminine) dalam konteks budaya masyarakat Yogyakarta. Penelitian ini melibatkan sumber data diantaranya informan yang terdiri dari artis cabaret show, penonton, dan masyarakat. Penelitian menggunakan pendekatan kajian budaya dengan model studi kasus tunggal terfokus yaitu dengan mengembangkan teori drag performance McNeal (1999) dan silang peran Dixon (1998). Validitas data penelitian diuji dengan peer debriefing sedangkan analisis data menggunakan model analisis interaktif Miles dan Huberman (2016). Penelitian ini menemukan bahwa pertama, terdapat ambivalensi oleh karena adanya fantasi melawan realitas, fantasi pembebasan dari berbagai tekanan, dan dalam berbagai elemen pembentuk seni pertunjukannya. Kedua, adanya kompleksitas pelaku baik berupa pemain drag queen, pemain dari laki-laki kemayu, dan pemain dari transgender menghasilkan bentuk seni berupa parodi dan parodi diri seniman Javanese cross gender.
\end{abstract}

Kata Kunci: drag performance, Javanese Cross Gender, Cabaret Show, Yogyakarta.

\begin{abstract}
This study examines the drag performance which includes drag queen, transgender drag, and feminine-male drag in the cultural context of Yogyakarta. The data were obtained from cabaret show players, audiences, and the public. The study used a cultural studies approach with a case study model using McNeal's (1999) drag performance theory and the cross-role of Dixon (1998). Data were analyzed using the interactive analysis model of Miles and Huberman (2016). This research finds that first, there is ambivalence due to the existence of fantasy against reality, fantasy of liberation from various pressures, and in the various elements that build this performing arts. Second, the complexity of actors in the form of drag queen players, feminine-male players, and transgender players produces a style in the form of parodies and self-parodies of Javanese cross gender artists.
\end{abstract}

Keyword: drag performance, Javanese Cross Gender, Cabaret Show, Yogyakarta.

\section{Pendahuluan}

Javanese cross gender dalam perkembangannya diterima dengan baik dan menjadi hiburan tiba-tiba mendapat penolakan dan kecaman dari beberapa lapisan masyarakat. Stigma negatif tentang kaum cross gender tersebut menyoroti bagaimana seseorang bersikap dan berpenampilan sesuai dengan jenis kelaminnya. Pandangan sinis terhadap kaum cross gender diantaranya dari kaum agamawan bahwa tindakan kaum cross gender tersebut melawan kodrat sebagai tindakan dosa dan haram. Stigma negatif 
datang pula dari sebagian masyarakat yang merasa jijik dengan ekspresi kegilaan kaum cross gender yang dianggap sebagai individu-individu dengan kepribadian yang tidak lazim atau menyimpang. Stigma negatif lain datang dari dunia pendidikan yang menganggap tindakan kaum cross gender kurang mendidik bagi moral generasi muda. Stigma-stigma negatif ini mengakibatkan kaum ini tidak begitu eksis di hadapan publik, sehingga tidak jarang kaum ini mengembangkan eksistensi dan kreativitas secara tersamar.

Seiring perkembangannya meskipun masih banyak kontroversi, individu-individu Lesbian, Gay, Biseksual dan Transgender (LGBT) juga berkembang di Indonesia, individu-individu tersebut berupaya memperlihatkan jati dirinya. Di sisi lain terdapat juga kaum transgender yang mulai dapat diterima keberadaannya di masyarakat dan dikenali bahwa mereka memiliki keterampilan yang bermanfaat bagi masyarakat.

Cabaret show di Resto Raminten Lantai 3 Gedung Hamzah Batik, Malioboro, kota Yogyakarta merupakan salah satu bentuk pengembangan kreativitas dari kaum Javanese cross gender baik itu laki-laki normal, transgender, maupun laki-laki kemayu. Pemahaman tentang kaum Javanese cross gender tersebut tidak lain suatu pemahaman yang meredefinisi gagasan McNeal (1999) tentang pertunjukan drag meliputi pertunjukan yang menyoroti drag queen, drag waria, dan drag dari pria gay. Pertunjukan Javanese cross gender berupa cabaret show didirikan oleh Hamzah Sulaiman yaitu seniman cross gender yang bergelut dalam seni pertunjukan tari dan kethoprak (teater tradisional). Cabaret show merupakan pertunjukan drag performance yang berupa pertunjukan lip sync. Hadirnya cabaret show di Yogyakarta jika dilihat dari konteks gender Indonesia modern, ketika ekspresi kaum transgender banyak mendapat kecaman di masyarakat, namun pada saat yang bersamaan mulai muncul pula keberanian para LGBT untuk mengungkapkan identitas dirinya. Hal tersebut menimbulkan pertanyaan apakah pertunjukkan cabaret show yang jika dilihat dari pementasannya menyerupai pertunjukan drag merupakan bentuk protes terhadap kekakuan konsep gender. Di balik hal-hal tersebut muncul pula pertanyaan apakah kesemuanya itu sekedar bentuk tindakan melanjutkan tradisi berkesenian sebagai bentuk penyelarasan fleksibilitas gender yang dikemas secara modern untuk merespon kebutuhan kesenian modern masyarakat Indonesia.

Kaum cross gender sebagai kaum yang rentan, melalui cabaret show kaum ini dapat lebih diterima. Hal tersebut terlihat dari perjalanan seni Indonesia dengan munculnya Didik Nini Thowok dalam berkreasi dengan memadukan kesenian traditional dan modern sehingga selalu merespon perkembangan selera masyarakat. Seniman cross gender pada generasi-generasi muda berikutnya dapat dikatakan sebagai bentuk upaya melanjutkan tradisi berkesenian Didik Nini Thowok dengan lebih mengadopsi budaya global.

Observasi awal penelitian cabaret show menemukan bahwa pemeran cabaret show berangkat dari kaum transgender, dari kaum laki-laki kemayu, dan dari laki-laki lurus yang hanya berpenampilan perempuan pada saat di panggung pentas. Kompleksitas para pelaku pertunjukan menimbulkan pertanyaan lebih lanjut tentang alasan mereka melakukan pertunjukkan yang mirip dengan pertunjukan drag queen di negara-negara barat. Apakah kaum ini juga bertujuan untuk mengejek kekakuan konsep gender dengan mengekspos pertunjukan drag, ataukah mereka justru sedang menghidupkan kembali tradisi fleksibilitas gender di atas pentas yang bisa sangat berbeda dengan kesehariannya. Seni yang sebagian dari pelakunya 
merupakan kaum transgender dan laki-laki kemayu memperlihatkan seni tidak sekedar performance, namun juga memperlihatkan performatif. Peniruan wanita berbakat dalam Butler (Butler, 1999; Morris, 1995) menciptakan tontonan yang mengekspos pertunjukan drug sebagai performatif.

Problematika yang mewarnai kaum cross gender dan cabaret show dapat ditarik suatu permasalahan yaitu bagaimanakah hubungan ekspresi pertunjukan drag dengan pelaku seninya kaum Javanese cross gender dalam pertunjukan cabaret show di kota Yogyakarta. Permasalahan ini memperlihatkan peristiwa kekinian yaitu contemporary social-culture yang diselesaikan dengan cara pandang kajian budaya dengan menerapkan teori drag performance McNeal(1999) dan seni silang peran Dixon (1998).

\section{Tinjauan Pustaka}

\section{Cross Gender dan Drag Performance dalam berbagai Seni Pertunjukan}

Pertunjukan dengan memerankan peran cross gender dalam dunia hiburan dan pertunjukan sebenarnya sudah berlangsung lama. Fenomena cross gender dalam berbagai pertunjukan diantaranya terdapat dalam drama tari, teater, dan pewayangan (Thowok, 2005). Buku yang merangkum tentang berbagai artikel tentang cross gender dalam berbagai pertunjukan antara yaitu buku karya Thowok (2005), artikelartikel dalam buku bunga rampai berjudul Cross Gender tersebut antara lain artikel tulisan Dibia yang memaparkan peran perempuan yang dibawakan oleh laki-laki dalam pertunjukan dramatari Arja Muani. Pramono memaparkan silang gender dalam dunia pewayangan yang diwujudkan melalaui karakterisasi maupun dalam kisahkisahnya. Widaryanto memaparkan dengan menjelaskan bahwa cross gender merupakan suatu bentuk rekayasa sosial dan kultural yang terdapat dalam seni pertunjukan tradisional Yogyakarta. Supanggah menjelaskan cross gender sebagai suatu bentuk simbol lintas. Soedarsono memaparkan tradisi cross gender melalui bentuk pertunjukan Cina yang dikenal dengan opera Peking. Singh memaparkan melalui bentuk seni pertunjukan di India bahwa perbedaan gender bukan hal yang dianggap penting, namun perbedaan gender justru membentuk ruang kreatif seniman.

Pemikiran silang peran dalam bentuk karya disertasi antara lain karya Dixon (1998) dengan judul "The Performance of Gender with Particular Reference to The Plays of Shakespeare". Disertasi tersebut berisi pemaparan pertunjukan karya Shakespeare oleh kaum laki-laki yang memerankan karakter perempuan oleh suatu perusahaan teater dengan produksi besar. Dalam panggung pertunjukan Shakespeare, silang gender dipengaruhi sex biologi di atas kreatifitas aktor dan sajian peran sehingga mempengaruhi perspektif penonton.

$$
\text { Pembahasan tentang drag }
$$
performance antara lain terdapat dalam artikel McNeal (1999) yang berjudul "Behind The Make-Up: Gender Ambivalence and The Double-Bind of Gay Selfhood in Drag Performance". Artikel tersebut menjelaskan tentang drag performance sebagai pertunjukan meniru perempuan yang meliputi pertunjukan drag queen yaitu laki-laki yang meniru perempuan hanya di atas panggung pentas, drag waria yaitu pertunjukan meniru perempuan yang dilatar belakangi pemerannya dari kaum waria, dan drag gay yaitu pertunjukan meniru perempuan yang dilatarbelakangi pemerannya dari kaum gay.

Cabaret di berbagai Pertunjukan di Dunia 
Bentuk dan perkembangan seni pertunjukan cabaret dari berbagai belahan dunia memiliki karakteristik yang berbedabeda. Masing-masing didasari peristiwaperistiwa yang melingkupi dimana seni tersebut berkembang sehingga membentuk tradisi yang mencerminkan ekspresi masyarakat setempat. Berikut berbagai artikel tentang cabaret yang mencerminkan ekspresi perjalanan seni cabaret didasari peristiwa-peristiwa yang membentuk hadirnya seni. Artikel yang berjudul "The German Cabaret Movement during the Weimar Republic "karya Lareau (1991) Sejak awal abad hingga akhir Perang Dunia Kedua seni cabaret merupakan ekspresi seniman Jerman untuk mengekspresikan perlawanan dan agitasi politik. Seiring perkembangannya cabaret terjebak sebagai suatu bentuk seni dan perdagangan. Artikel mengemukakan perjalanan cabaret Jerman dimana seni sebagai ekspresi perlawanan terhadap situasi politik yang sedang berkembang, sejalan dengan berkembang seni dan situasi yang berkembang seni pada akhirnya menjadi seni komersial. Artikel lain yaitu artikel "Le « cabaret new-yorkais »: note d'usage" karya Protat (2005) menjelaskan tentang cabaret di New York. Artikel Protat memaparkan bahwa setelah Perang Dunia II atau kurang lebih sejak tahun 1963, cabaret pada club-club bertahan sebagai seni hiburan populer. Artikel Protat lebih memahami seni cabaret sebagai seni hiburan semata, bahkan seni cabaret menjadi kekuatan utama dan daya tarik pengunjung sehingga club atau tempat hiburan malam dapat tetap bertahan. Artikel lain yang berjudul "Dramaturgy, Citizenship, and Queerness: Contemporary Mexican Political Cabaret" karya Alzate (2010) menjelaskan tentang cabaret Mexico kontemporer. Artikel ini lebih menyoalkan para senimansenimannya, di mana seniman cabaret
Mexico ini dianggap memiliki penyimpangan dari norma sexual. Cabaret Mexico mengekspresikan pertentangan terhadap dominasi gender dan seksualitas dalam wacana nasional Mexico.

Beberapa penelitian dan artikel Indonesia yang memaparkan tentang cabaret, khususnya pertunjukan cabaret show yang berkembang di Yogyakarta antara lain adalah penelitian yang berjudul "Ekspresi Estetis Penari Cross Gender dalam Cabaret Show di Oyot Godhong Mirota Batik Yogyakarta" karya Heni Siswantari (2015) yang dimuat di Electronic Theses \& Dissertations (ETD) Gadjah Mada University. Tulisan Siswantari (2015) mengkaji masalah bentuk ekspresi estetis penari dan relasi cross gender terhadap ekspresi estetis dalam panggung pentas. Artikel berjudul "Fenomena Cross-Gender dalamRaminten 3 Cabaret Show, Mirota Batik, Yogyakarta" karya Muchibur Rochman dan V. Indah Pinasti (2015) dimuat di ejurnal Pendidikan Sosiologi UNY. Artikel Rochman dan Pinasti (2015) mengkaji faktor-faktor yang melatarbelakangi keikutsertaan individu dalam Raminten 3 cabaret show dan sejarah proses terselenggaranya pertunjukan Raminten 3 cabaret show, serta mendiskripsikan kehidupan talent atau pemeran crossgender dalam Raminten 3 cabaret show. Dari berbagai penelitian terdahulu tersebut belum ada penelitian yang mengkaji seni cabaret show Yogyakarta dari aspek drag performance atau pertunjukan meniru wanita, sehingga dalam kesempatan ini peneliti berupaya mengetengahkan hasil penelitian tentang cabaret show di Yogyakarta sebagai seni kaum cross gender yang dikaji dari aspek drag performance.

\section{Seniman dan Aspek-aspek Drag Performance}


Drag performance secara garis besar dalam McNeal(1999) meliputi drag queen, drag gay, dan drag waria. Drag queen merupakan tindakan meniru wanita dari laki-laki lurus yang hanya meniru wanita di atas panggung pentas. Drag Performance dari subyektivitas laki-laki gay ditandai adanya suatu dialektika pelanggaran dan konformitas berasal dari konflik. Suatu konflik baik maskulin dan feminin sebagai bentuk representasi diri yang memiliki ikatan ganda kedirian. Drag waria merupakan tindakan peniruan wanita oleh subyektivitas kaum waria. Cabaret show yang mengekspos drag performance menampilkan pertunjukan drag queen darilaki-laki lurus, drag waria atau transgender sebagai ekspresi subyektivitas dari laki-laki transgender, dan drag performance yang memperlihatkan subyektivitas dari lakilaki kemayu (feminine). Kemayu merupakan penyebutan sifat feminine bagi perempuan Jawa. Pemahanan konsep drag performance dalam permasalahan ini mengalami suatu redefinisi sebagai suatu penyesuaian terhadap kondisi budaya masyarakat Yogyakarta.

McNeal (1999) memaparkan bahwa di atas panggung pertunjukan drag performance memperlihatkan konflik dinamis dan ambivalensi dari nuansa glamor dan komedi. Di samping hal tersebut kompleksitas pelaku drag performance memperlihatkan adanya parodi dan parodi diri. Pertunjukan cabaret show secara visual yang terkesan glamor dan komedi sesungguhnya di balik itu terdapat konflik dinamis dan ambivalensi. Pemeran drag performance yang berasal dari laki-laki lurus cenderung melakukan parodi, sedangkan drag performance dari transgender dan laki-laki kemayu melakukan parodi diri.

\section{Metode Penelitian}

Penelitian tentang Cabaret show yang menyajikan pertunjukan kaum cross gender dengan mengekspos drag performance dilaksanakan di resto Raminten 3, Jl. Margomulyo No. 9 Malioboro Lantai 3 Gedung Hamzah Batik. Penelitian ini merupakan penelitian kualitatif menggunakan model studi kasus tunggal terfokus, di mana permasalahan merupakan satu hal berupa permasalahan khusus, unik, berbeda, dan bahkan menyimpang. Penelitian juga terfokus pada kasus tertentu (Ratna, 2016) sehingga pendekatan yang sesuai adalah pendekatan eksploratif.

Penelitian tentang drag performance oleh pelaku cross gender dalam cabaret show di Yogyakarta menggunakan sumber data penelitian berupa informan yang benarbenar menguasai persoalan. Sumber data informan antara lain: Bayu, 40 tahun, artis drag performance yang fokus pada penampilannya sebagai drag queen; Mamuk Rohmadona, 36 tahun, artis drag performance dari laki-laki kemayu; dan Sarita Kamasutra, 40 tahun, artis drag performance yang berasal dari individu transgender. Penelitian tentang pertunjukan ini didukung dengan sumber data berupa dokumen foto dan video pementasan cabaret show. Analisis data penelitian ini menggunakan model interaktif (Miles \& Huberman, 2016). Langkah-langkah penelitian yang meliputi pendekatan, teknik, dan strategi, mampu menjelaskan hubungan ekspresi drag performance dengan pelaku seninya kaum Javanese cross gender dalam pertunjukan cabaret show di Yogyakarta berdasarkan teori drag Performace McNeal (1999) dan teori silang peran Dixon (1998). 


\section{Hasil Dan Pembahasan}

\section{Ambivalensi dalam Pertunjukan Cabaret Show di Yogyakarta}

Cabaret show merupakan pertunjukan yang menampilkan pemeran cross gender sebagai prioritas. Silang peran yang ditampilkan merupakan pertunjukan pria yang memerankan peran wanita. Pertunjukan dengan mengekspos drag performance atau pertunjukan meniru wanita dalam cabaret show ini tergolong genre baru dalam pertunjukan Indonesia. Pertunjukan drag dikemukakan McNeal (1999) sesungguhnya di balik pertunjukan yang glamor dan komedi terdapat konflik dinamis dan ambivalensi. Ketidaksesuaian antara fisik dengan jiwanya yang ambivalen inilah yang memancing lelucon dan parodi humor. Ambivalensi memperlihatkan ketidaksadaran yang saling bertentangan baik sikap atau penampilannya terhadap pandangan norma ideal perempuan sesuai konsepsi masyarakat pada umumnya. Ambivalen yang terdapat dalam pertunjukan cabaret show antara lain menampilkan pertunjukan yang terkadang terkesan glamor sehingga membuat penontonnya begitu terkagum-kagum dan takjub dibuatnya. Ambivalen terdapat pula pada pertunjukan yang menampilkan pemeran dengan karakter sederhana namun atraktif, lincah, dan konyol. Sikap dan penampilan pemain memancing dan membawa penonton pada suasana rileks dan komedi.

Ambivalensi secara etimologi dimaknai sebagai perasaan tidak sadar yang paling bertentangan terhadap situasi yang sama atau terhadap seseorang pada waktu yang sama (KBBI on line, 2019). Pemahaman tersebut akan menarik untuk meninjau pertunjukan cabaret show yang menampilkan drag performance. Dalamdrag performance atau pertunjukan meniru wanita terdapat beberapa hal yang dapat dilihat sebagai ambivalensi. Penggunaan busana secara glamor misalanya dikemukakan Rahmadona (Rahmadona, wawancara, Agustus 2, 2019) "Kostum-kostum saya tu ya full payet gitu! Kalau udah full payet harga baju aja berapa...iya kan! Rambutku, satu rambut itu bisa $R p$. 750.000,00 sampai $R p 1$. 500.000,00! Itu baru harga rambutnya, belum yang lain seperti baju yang full payet, sepatu, dan aksesoris lainnya!" Terdapat ambivalensi untuk memenuhi penampilan layaknya perempuan secara total sehingga bertentangan dengan jenis kelamin yang sebenarnya. Hal lain terdapat dalam penampilannya yang meniru perempuan terkadang melupakan bahwa kekuatan perempuan ideal yang sesungguhnyapun tidak seekstrim atau sekuat yang diperagakan sehingga memancing tawa bagi penontonnya. Dikemukakan Rahmadona (wawancara: 2 Agustus 2019) "Menurut saya kalau hanya sekedar lip sync sepertinya kurang menarik ya, jadi saya nge-dance sambilnya nyanyi tidak sekedar lips sync saja. Atraksi-astraksi panggung saya keluarkan, sebisa mungkin skile, tempo, dan powerku kalau bisa lebih dari yang biasa." Demikian ini memperlihatkan bahwa strategi untuk menarik penonton adalah dengan atraksi dan penampilan yang melebihi rata-rata. Hal tersebut merupakan bentuk ketidaksengajaan atau ketidaksadaran bahwa terdapat pertentangan bagaimana konsepsi dalam menempatkan perempuan ideal sesuai peran yang dibawakan. Sebagai bentuk pemenuhan terhadap kepentingan pertunjukan yang menarik dan memancing tawa penonton, maka konsepsi perempuan ideal masyarakat bertentangan dengan konsepsi ideal perempuan dalam pertunjukan.

Pemain cross gender yang sadar maupun tidak disadari telah melakukan pertentangan baik dalam hidup maupun dalam berkesenian memunculkan beragam pendapat dari masyarakat. Pendapat tersebut ada yang positif ada yang negatif. Adapun pendapat masyarakat yang kurang 
mendukung dengan kehadiran kaum cross gender sebagai berikut: memposisikan perannya terlepas dari jenis kelaminnya, bisa dikatakan bahwa aktoraktor tersebut telah mampu mencapai esensi

\begin{tabular}{|c|c|c|c|}
\hline No & $\begin{array}{c}\text { Ketidaksadaran } \\
\text { ambivalensi } \\
\text { sesuai cara } \\
\text { pandang } \\
\text { masyarakat }\end{array}$ & $\begin{array}{c}\text { Tanggal } \\
\text { Wawancara }\end{array}$ & Penilaian Masyarakat terhadap kaum cross gender \\
\hline 1. & Kepercayaan & $\begin{array}{l}\text { Wimbo: } \\
28 \text { April } \\
2018\end{array}$ & $\begin{array}{l}\text { "Mereka itu banci, orang-orang seperti itu kelihatan } \\
\text { kalau mereka jauh dari agama" }\end{array}$ \\
\hline 2. & Kodrat & $\begin{array}{l}\text { Santyo: } \\
\text { 14 Januari } \\
2018\end{array}$ & $\begin{array}{l}\text { "Tuhan hanya menciptakan laki-laki dan perempuan, } \\
\text { doakan saja mereka kembali ke kodratnya" }\end{array}$ \\
\hline 3. & $\begin{array}{l}\text { Kodrat dan } \\
\text { Pendidikan }\end{array}$ & $\begin{array}{l}\text { Rusmi: } \\
29 \mathrm{Mei} \\
2020\end{array}$ & $\begin{array}{l}\text { "Laki-laki dan perempuan sudah mempunyai kedudukan } \\
\text { dan peran sendiri-sendiri, sejak bayi dilahirkanpun sudah } \\
\text { mempunyai bentuk dan fisik yang jelas sesuai takdirnya. } \\
\text { Adapun tabiat keperempuanan atau kelelakian } \\
\text { merupakan perilaku yang mana kadang timbul dalam diri } \\
\text { seseorang yang mempunyai kelainan itu, hal itu bisa } \\
\text { dirubah dalam diri masing-masing dengan pola } \\
\text { pendidikan secara agama, psikologi, dan sosial dengan } \\
\text { ditanamkannya pola pikir dan tingkah laku sebagaimana } \\
\text { mestinya sebagai laki-laki maupun perempuan sejati." }\end{array}$ \\
\hline 4. & Psikologi & $\begin{array}{l}\text { Megantara: } \\
29 \text { Mei } \\
2020\end{array}$ & $\begin{array}{l}\text { "Dekat-dekat dengan orang yang kayak gitu itu rasanya } \\
\text { gimana gitu... ada rasa takut-takut gimana" }\end{array}$ \\
\hline 5. & $\begin{array}{l}\text { Kodrat } \\
\text { Moral }\end{array}$ & $\begin{array}{l}\text { Margono: } \\
29 \mathrm{Mei} \\
2020\end{array}$ & $\begin{array}{l}\text { "Manusia diciptakan hanya terdiri dari laki-laki dan } \\
\text { perempuan, banci tidak dikenal. Kalaupun ada banci di } \\
\text { sekeliling kita, berarti dia menyalahi ketentuan } \\
\text { kodratnya. Saya berpikir meskipun seni tetapi jangan } \\
\text { sampai merusak moral anak bangsa dengan menampilkan } \\
\text { waria. }\end{array}$ \\
\hline
\end{tabular}

Tabel 1. Pandangan masyarakat dari berbagai aspek yang kurang mendukung terhadap keberadaan kaum cross gender

Terlepas dari pandangan-pandangan negatif masyarakat, kemampuan penguasaan berbagai peran dalam pertunjukan merupakan tuntutan bagi seniman, begitu pula kemampuan bersilang peran. Esensi dari penguasaan karakter adalah kemampuan pemeran yang dapat melepaskan diri dari karakter dan jenis kelamin aslinya. Dixon (1998) mengemukakan aktor yang baik merupakan aktor yang mampu mengambil peran yang terlepas dari jenis kelamin sebenarnya, aktor tersebut harus mampu mencapai esensi karakter, esensi yang berbeda dengan jenis kelamin sebenarnya. Semua aktor drag performance telah mampu karakter menjadi seorang perempuan, esensi yang berbeda dengan jenis kelaminnya yang sebenarnya adalah seorang laki-laki. Meskipun kadang kala disebabkan oleh karena peran yang dibawakan selalu dekat dengan kelembutan identiknya perempuan, membuat pemeran terbawa memiliki sifat dan pembawaan yang lembut seperti layaknya perempuan dalam kehidupan.

Penampilan yang menarik menjadi keutamaan dalam setiap penyajian pertunjukan. Karakterisasi didukung dengan make-up yang tepat dan baik akan dapat menyempurnakan penampilan. Sambutan Soedarsono dalam buku karya Thowok 
(2012) mengungkapkan sebenarnya dalam dunia stage make-up ada corektive make-up, character make-up, fantasy make-up, dan likeness make up. Adapun yang termasuk corrective make-up adalah pria menjadi wanita yang hanya memerlukan sedikit corrective make-up serta sanggul pasangan. Namun tampaknya gagasan tersebut hanya tepat untuk make-up pada peran perempuan tradisional, seperti pada bagian pembuka cabaret show dengan menyajikan tari tradisional Jawa yang hanya memerlukan make-up cantik dengan sanggul pasang. Pertunjukan cabaret show di Yogyakarta secara umum baik pembuka, isi, maupun penutup ternyata menyajikan pertunjukan kekinian yang memanfaatkan semua aspek baik corrective make-up, character make-up, fantasy make-up, dan likeness make up. Pada salah satu bagian tertentu akan menampilkan dengan memanfaatkan corrective make-up, namun di bagian-bagian lain akan ditemukan meke-up dengan memanfaatkan character make-up, fantasy make-up atau mungkin likeness make up. Hal tersebut sesuai dengan sifat seninya yang menyajikan konsep kekinian dan contemporary.

Membangun karakter perempuan dapat didukung dengan penggunaan make-up yang tepat dan sesuai sehingga dapat membantu mengurangi kesan kelakilakiannya. Adapun tips-tips Thowok dalam membuat karakter wanita pada wajah pria disampaikan sebagai berikut.

Membuat karakter wanita pada wajah pria, kuncinya adalah pemakaian foundation w arna cokelat terang yang cenderung tebal untuk untuk menutup anatomi wajah yang menunjukkan kesan pria. Bagaimana mata dan alis merupakan salah satu kunci merubah karakter pria menjadi wanita, sehingga membentuk bagian mata harus tepat. Misalnya pemakaian eye shadow, eye liner, scotch mata, bulu mata, juga pembuatan alis yang melengkung halus sesuai dengan bentuk mata (Thowok, 2012).
Porsi dan warna foundation yang tepat, membentuk mata dan alis yang dapat membangun kesan perempuan menjadi hal yang perlu diperhatikan. Penguasaan teknik dapat membantu mengurangi kesan kelakilakian, di samping make-up yang memadai tentunya.

Busana yang dipergunakan pada drag performance dalam Dixon (1998) pada dasarnya merupakan suatu tindakan aktor laki-laki mengadopsi busana perempuan. Cabaret show sebagai pertunjukan yang menayajikan pertunjukan kekinian namun masih melibatkan unsur-unsut tradisional dalam kemasan pertunjukannya, maka adopsi busana yang dilakukan merupakan adopsi busana modern dan busana tradisional. Pada bagian opening yang menampilkan tari tradisional, busana yang dipergunakan merupakan busana yang telah menjadi tradisi tari tersebut. Penggunaan seperti kain, baju, sanggul, hingga perhiasan yang sudah identik dengan tari tradisional tersebut juga harus tepat dan sesuai. Pertunjukan drag atau pertunjukan meniru perempuan pada sajian modern, tentunya busana yang diadopsi merupakan busana-busana modern yang biasa dipergunakan pada artis yang lebih terkenal. Salah satu contohnya busana yang dipergunakan artis penyanyi dengan selalu menampilkan busana yang memperlihatkan lekuk tubuh atau rok dengan belahan tinggi, warna busana cerah dan mencolok, berhiaskan payet-payet yang memiliki efek mengkilat, dan lain sebagainya.

Ditinjau dari iringan musiknya, cabaret show terdiri dari iringan modern dan tradisional. Musik bagian pembuka yang menghadirkan iringan musik tari tradisional Jawa, memperlihatkan seni ini adalah seni modern namun tetap mempertahankan nilainilai kearifan lokal Jawa. Iringan yang memperlihatkan kesan keperempuanan dalam pandangan ideal yaitu iringan dengan karakter musik lembut dan tenang. Iringan tari Jawa identik dengan kesan lembut dan 
agung. Pada bagian isi dan penutup pertunjukan cabaret show menghadirkan pertunjukan lip sync dengan penampilan iringan dari berbagai jenis musik. Teknik lip sync yang dilakukan dalam pertunjukan menghadirkan vocal perempuan, di samping menciptakan citra perempuan dalam pertunjukan juga memudahkan teknik kerja bagi senimannya. Berbagai iringan musik seperti pop, slow rock, hingga dandut koplo disajikan dalam pertunjukan cabaret show. Salah satu iringan music dalam pertunjukan cabaret show adalah dangdut koplo, musik jenis ini memiliki ciri antara lain ekspresif, keras, dan kadang menghentak-hentak. Dalam pandangang masyarakat Jawa dan pandangan idealnya perempuan Jawa yang lembut dan memegang tata krama yang tinggi, mengesankan terdapat ambivalensi dengan hadirnya music dangdut koplo tersebut. Ketidaksadaran ambivalensi yang terjadi dikarenakan disamping seni menghadirkan kreativitas, disisi lain seni memiliki tujuan pemancing lelucon dan parodi humor di atas panggung pentas.

Pentas cabaret show dalam mengekspos drag performance didukung dan dibantu oleh permainan lampu. Aksi-aksi panggung pemeran cross gender sebagai pertunjukan yang ditonjolkan dibantu dengan permainan lampu spot. Padmodarmaya (1988) menyampaikan bahwa lampu yang dapat dipergunakan untuk mengikuti jalannya pemeranan ke mana pun pemeran bergerak adalah lampu follow spot. Cara penggunaan lampu follow spot apabila lampu ini sedang bekerja, maka cahaya lampulampu lain di daerah pemeranan dapat diredupkan atau bahkan dimatikan. Teknik dan penggunakan lampu follow spot seperti tersebut dapat dipergunakan untuk memberikan kesan penonjolan dan keterfokusan pemain cross gender sebagai pemain central. Sementara untuk mendukung pertunjukan memiliki kesan ringan dan komedi dapat menggunakan cahaya lampu dengan efek warna-warni.

Cabaret show Yogyakarta

berdasarkan seniman pelakunya dapat dikategorikan dalam pertunjukan drag queen, pertunjukan drag waria (transgender), dan pertunjukan laki-laki kemayu (feminine). Bentuk pertunjukan semacam ini meredefinisi pandangan McNeal dengan disesuaikan dengan kehidupan masyarakat Yogyakarta. Pandangan McNeal (1999) ekspresi drag performance meliputi ekspresi pertunjukan drag queen, drag waria, dan ekspresi pertunjukan kaum gay. Kehidupan masyarakat Yogyakarta yang masih terkesan tertutup dan malu-malu tentang adanya kehidupan kaum transgender dan kaum gay membuat aktivitas dan kreativitas pelakunya berbeda dan terkesan tersamar. Bentuk kreativitas berupa pertunjukan cabaret show secara umum dapat disebut sebagai kreativitasnya kaum cross gender. Meskipun pertunjukan ini merupakan bentuk kreativitas meniru perempuan, namun subjektifitas pelaku tidak serta merta dapat dihilangkan. Dengan demikian cabaret show tidak saja menghadirkan performance, namun juga menghadirkan sebagian dari apa yang menjadi performatifitasnya. Praktik semacam ini tidak disadari sejalan dengan pemikiran Butler (1999) dan Morris (1995) bahwa dengan meniru wanita sebagai suatu bakat dapat menciptakan tontonan yang performatif. Hal-hal yang dapat dilakukan untuk dapat meniru wanita berdasarkan Butler (1999) dapat dilakukan dengan berimaginasi menjadi keperempuanan seperti perempuan sebenarnya sehingga mengaburkan identitas kelaki-lakiannya, atau dapat juga dengan berimaginasi dengan menghadirkan sifat feminin sehingga audien terbawa konsentrasinya dan hanya terfokus pada apa yang mereka tonton. Hal-hal tersebut tidak disadari telah banyak dipraktikkan pemeran drag performance. Seperti dikemukakan Rahmadona 
(wawancara, Agustus 2, 2019) berikut "Saya berusaha menghadirkan tidak hanya sekedar cantik tapi saya bener-bener membuat penonton pulang itu punya cerita yang akhirnya membuat penonton datang kembali, makanya saya dalam pertunjukan selalu dipentaskan di bagian terakhir" Penonton yang awalnya ragu-ragu atau memandang sinis dengan tontonan jenis ini, cara Butler dan praktik yang dilakukan Rahmadona dapat dipergunakan untuk lebih dapat meyakinkan penontonnya.

\section{Parodi dan Parodi Diri dalam Cabaret Show di Yogyakarta}

Pertunjukan cabaret show di Yogyakarta menyajikan pertunjukan drag yang meliputi pertunjukan dari laki-laki lurus atau drag queen yang memerankan peran perempuan hanya di panggung pentas saja, pemain drag dari laki-laki kemayu atau feminine, dan pemain drag dari individu trans gender. McNeal (1999) menjelaskan terdapat adanya parodi dan parodi diri dalam pertunjukan drag. Berdasarkan tiga tipe pemain drag tersebut maka dalam penampilannya, pertunjukan cabaret show menyajikan pertunjukan parodi dari laki-laki lurus, dan parodi diri dari laki-laki kemayu dan waria. Sesuai dengan karakter pemainnya maka cabaret show dapat digambarkan dalam suatu bagan 1 .

Parodi yang dihadirkan laki-laki lurus antara lain dengan mengimitasi atau menciptakan gerakan baru menyesuaikan dengan karakter dan sifat yang dimiliki perempuan. Sementara parodi diri yang dihadirkan laki-laki kemayu dan waria antara lain menampilkan tidak saja sekedar mengimitasi atau menciptakan gerakan baru, namun unsur subyektivitas dan sifat keperempuan pelaku ikut membentuk karakter penampilannya itu. Hal ini menunjukkan bahwa parodi menyajikan raga, jiwa, dan pikir sebagai ekspresi berkesenian, sementara parodi diri menghadirkan raga, jiwa, dan pikir yang tidak saja merupakan ekspresi berkesenian, namun juga merupakan bentuk ekspresi jiwa keperempuanan pelakunya. Fokus dari tiga tipe pelaku tersebut berbeda-beda. Laki-laki lurus fokus pada keterampilan bermain peran, laki-laki kemayu dan waria focus pada kebahagiaan hidup dan hasrat jiwa keperempuanan.

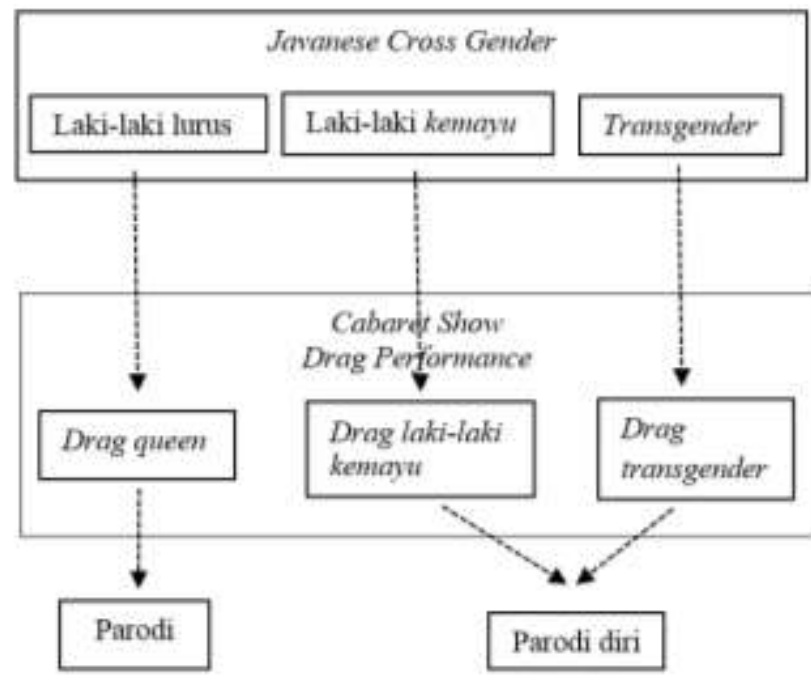

Bagan 1. Parodi dan Parodi Diri Drag

Performance oleh Kaum Cross Gender dalam Cabaret Show di Yogyakarta.

\section{Simpulan}

Hubungan ekspresi drag performance dengan pelaku seni yaitu kaum Javanese cross gender antara lain memperlihatkan ekspresi ambivalensi dari diri melawan realitas, ambivansi dari berbagai tekanan masyarakat, dan ambivalensi dalam penampilannya di atas panggung pertunjukan. Ambivalensi memperlihatkan ekspresi jiwa melawan realitas dari diri yang sesungguhnya lakilaki untuk hadir sebagai perempuan melalui pertunjukan cabaret show. Hal ini cenderung dirasakan dari kaum laki-laki 
kemayu dan waria, sementara dari kaum laki-laki lurus, penampilannya hanya sebagai ekspresi berkesenian semata.

Adanya suatu fantasi pembebasan dari berbagai tekanan masyarakat yang dirasakan oleh kaum cross gender diperlihatkan dengan mengekspresikan jiwa keperempuanan melalui berkesenian. Tidak tercapainya hasrat jiwa kewanitaan di lingkungan masyarakat, khususnya bagi individu-individu dari laki-laki kemayu dan dari kaum waria menyebabkan kedua kaum ini berupaya mengekspresikan hasrat jiwa keperempuanan melalui peran cross gender dalam cabaret show.

Ambivalensi dapat terlihat melalaui ekspresi jiwa dan penampilan pemain Javanese cross gender dalam berkesenian. Ambivalnsi dalam pertunjukan kaum Javanese cross gender di panggung pertunjukan cabaret show antara lain dapat dikelompokkan sebagai berikut:

\begin{tabular}{|c|c|c|c|}
\hline No & $\begin{array}{l}\text { Kategori } \\
\text { Artis }\end{array}$ & Eskpresi & Fokus \\
\hline 1 & Drag Queen & berkesenian & Keterampilan bermain peran \\
\hline 2 & $\begin{array}{l}\text { Laki-laki } \\
\text { kemoyu }\end{array}$ & $\begin{array}{l}\text { berkesenian } \\
\text { \& jiwa } \\
\text { keperempua } \\
\text { nan }\end{array}$ & $\begin{array}{l}\text { Kebahagiaan hidup \& hastat } \\
\text { jiwa }\end{array}$ \\
\hline 3 & Transgender & $\begin{array}{l}\text { berkesenian } \\
\text { \& jiwa } \\
\text { keperempua } \\
\text { nan }\end{array}$ & $\begin{array}{l}\text { Kebahagiaan hidup \& hasrat } \\
\text { jiwa }\end{array}$ \\
\hline
\end{tabular}

Tabel 2. Elemen pembentuk seni yang mengalami ambivalensi antara lain

\begin{tabular}{|c|c|c|c|c|}
\hline No & Eilemen & Penampilan & Ambrvalenss & Efek \\
\hline 1 & Busana & $\begin{array}{l}\text { Glamor, } \\
\text { Memperlihatkan } \\
\text { lekuk tubuh, belahan } \\
\text { rok tinggit, warna } \\
\text { mencolok }\end{array}$ & $\begin{array}{l}\text { Ketudak sestuaian antara } \\
\text { fisik laki-laki dengan } \\
\text { jiwa }\end{array}$ & $\begin{array}{l}\text { Mermancing } \\
\text { lelucont dan } \\
\text { parodi humot }\end{array}$ \\
\hline 2 & Gerak & $\begin{array}{l}\text { Arrakitif, lineah, dan } \\
\text { konyol }\end{array}$ & $\begin{array}{l}\text { Ketidaksesuaian antara } \\
\text { power laki-laki dengan } \\
\text { power wanita ideal yang } \\
\text { lembut dan sopen }\end{array}$ & $\begin{array}{l}\text { Memancing } \\
\text { lehicon dan } \\
\text { parodi hamor }\end{array}$ \\
\hline 3 & Musik & Dangdut koplo & $\begin{array}{l}\text { Inama musik yang } \\
\text { menghentak-hentak } \\
\text { berlawanan dengan nifat } \\
\text { halus dan sopan wanita }\end{array}$ & $\begin{array}{l}\text { Memancing } \\
\text { lelucon dan } \\
\text { parodi bumot }\end{array}$ \\
\hline
\end{tabular}

Tabel 3. Tabel elemen penampilan
Hubungan drag performance dengan pelakunya kaum Javanese cross gender merupakan ekspresi parodi dan parodi diri untuk menciptakan lelucon dan parodi humor. Javanese cross gender merupakan redefinisi dari makna drag performance dalam budaya barat. Javanese drag performance yang terbentuk oleh kaum Javanese cross gender memiliki karakteristik tersendiri yang menjadi pembeda seni ini dengan seni cabaret lain.

\section{Referensi}

Alzate, G. (2010). Dramaturgy, Citizenship, and Queerness: Contemporary Mexican Political Cabaret. Latin American Perspectives, 37(1), 6276. http://www.jstor.org/stable/ 20684698

Butler, J. (1999). Gender Trouble: Feminism and the Subversion of Identity. Routledge.

Dixon, L. (1998). The performance of gender with particular reference to the plays of Shakespeare [Doctoral dissertation, Middlesex University]. https://eprints.mdx.ac.uk/6384/1/Dix on-performance_of_genda.phd.pdf (Diakses 7 Mei 2020).

KBBI online. (n.d.). Ambivalensi. Kamus Besar Bahasa Indonesia online. Diakses Juli 23, 2020, dari https://kbbi.web.id/ambivalensi.

Lareau, A. (1991). The German cabaret movement during the Weimar Republic. Theatre Journal, 43(4), 471-490. http://www.jstor.org/ stable/3207977.

Lareau, A. (1991). The German cabaret movement during the Weimar Republic. Theatre Journal, 43(4), 471-490. https://www.jstor.org/stable/320797 7

McNeal, K. E. (1999). Behind the Make-Up: Gender Ambivalence and the 
Double-Bind of Gay Selfhood in Drag Performance. Ethos, 27(3), 344-378. https://doi. org/10.1525 /eth.1999. 27.3.344

Miles, M. B. \& Huberman, A. M. (2014). Analisis Data Kualitatif: Buku Sumber Tentang Metode-Metode Baru (T. R. Rohidi, Trans.). UIPress.

Morris, R. C. (1995). All made up: Performance theory and the new anthropology of sex and gender. Annual review of anthropology, 24(1), 567-592. https://doi.org/10. 11 46 /annurev.an.24.100195.003031

Padmodarmaya, P. (1988). Tata dan Teknik Pentas. Balai Pustaka.

Protat, J. (2005). Le « cabaret new-yorkais »: note d'usage. Revue française d'études américaines, 104(2), 1930. https://doi.org/10.3917/rfea.104. 0019

Ratna, N. K. (2016). Metodologi Penelitian Kajian Budaya dan Ilmu Sosial Humaniora pada Umumnya. Pustaka Pelajar.
Rochman, M. M. \& Pinasti, V.I.S. (2015). Fenomena Cross-Gender dalam Raminten 3 Cabaret Show, Mirota Batik, Yogyakarta. [Skripsi, Universitas Negeri Yogyakarta]. https://journal.student.uny.ac.id/ojs/i ndex.php/societas/article/view/3775.

Siswantari, H. 2015. Ekspresi Estetis Penari Cross Gender Dalam Cabaret Show Di Oyot Godhong Mirota Batik Yogyakarta. [Tesis Master, Universitas Gadjah Mada]. http://etd.repository.ugm.ac.id/home/ detail_pencarian/88124

Thowok, D. N. (2005). Cross gender. Sava Media bekerjasama dengan LPK Tari Natya Lakshita.

Thowok, D. N. (2012). Stage Make-up by Didik Nini Thowok. Gramedia Pustaka Utama. 